\title{
Heart of Learning: Pedagogical Practices Amongst Islamic Education Novice Teachers in the $21^{\text {st }}$ Century
}

\author{
Tengku Sarina Aini Tengku Kasim \\ University of Malaya, tgsarina@um.edu.my \\ Fatimah Sahida Abdurajak \\ University of Malaya, fsahida@siswa.um.edu.my
}

\begin{abstract}
A number of issues and challenges have been faced by novice teachers such as the difficulties in translating their knowledge into action, managing the classroom, finding suitable teaching approaches and more. Thus, this study seeks to address and examining the understanding and pedagogical practices of novice teachers as they grapple with essential aspects of teaching. Moreover, it provides an insight into the actual application of their teaching and learning approaches which they adopt throughout a limited experience during their initial years of teaching. This study was conducted on ten Islamic education novice teachers in secondary schools from four different states in Malaysia. The data were collected by using semi-structured individual interviews. The results that emerge from these findings are teachers' application of using studentcentred learning and their acceptance in imposing $21^{\text {st }}$ Century Education.
\end{abstract}

Keywords: Islamic education novice teachers, pedagogical practices, student-centred learning, $21^{\text {st }}$ century education

\section{Introduction}

Since the fourth industrial revolution has been publicised in 2015, the education dynamic has rapidly advanced in order to cope with the rising changes in terms of the technology of production from human-made into cyber-physical systems. This technological innovation brought a wave of accelerating pace of change, in which it can be accessed instantly and deliver a greater impact. ${ }^{1}$ In addressing the purpose of preparing current generation with the right skill set and knowledge, it is essential to ensure effective and immediate transformation of the delivery of education. The act of transforming education can be seen in Malaysia, whereas the former Minister of Higher Education Malaysia, Datuk Seri Idris

1 World Economic Forum, "ASEAN 4.0: What Does the Fourth Industrial Revolution Mean for Regional Economic Integration?" (Geneva: World Economic Forum and Asian Development Bank, 2017). 
Jusoh has given his mandate to revamp the Malaysian higher education system by embracing 'Teaching and Learning 4.0' in order to remain competitive and relevant with current transformation. ${ }^{2}$

The Islamic education teacher training programme is no exception. The revamp is vital as it has the responsibility in developing student-teachers dynamics that can deal with 21 st century education in requiring complex thinking without neglecting the values of Islam. The $21^{\text {st }}$ century integration and development in education resulted in a huge shift in Malaysia's education system, by the introduction of Secondary School Standard Curriculum or in Malay, Kurikulum Standard Sekolah Menengah (KSSM) in 2017 and Primary School Standard Curriculum or Kurikulum Standard Sekolah Rendah (KSSR) which was implemented in $2011^{3}$ to replace the old curriculum that was too focusing on the content of the subjects. KSSM suggesting that teaching and learning strategies should be learnercentred, collaborative, fun and emphasising the development of thinking skills and soft skills. ${ }^{4}$ Hence, Islamic education that is still bounded by traditional approaches in teaching and learning, need to offset the teachers' mindset in terms of the usage of various teaching methods as well as empowering students in their learning.

Student-centred learning demands for applying "methods that increase awareness of what is done and why it is done, foster higher order skills, activate prior knowledge and experience, help develop independent learning skills, provide multiple representations of the content and encourage students to take responsibility for their own learning". 5 Alternatively, it is opposite with the traditional teacher-centred approaches. The outlook of

2 Maizatul Ranai, “2018 MANDATE : Embracing Industry 4.0,” Ministry of Higher Education Malaysia, 2018, http://news.mohe.gov.my/2018/01/27/2018mandate-embracing-industry-4-0/.

3 MoE Malaysia, Buku Penerangan Kurikulum Standard Sekolah Menengah (Putrajaya: Curriculum Development Division, Ministry of Education, 2016), 3.

4 MoE Malaysia, Buku Penerangan Kurikulum Standard Sekolah Menengah, 54.

5 Gülen Onurkan Aliusta and Bekir Özer, "Student-Centred Learning (SCL): Roles Changed?," Teachers and Teaching: Theory and Practice, 23, no. 4 (2017): 422. 
teacher-centred has been stigmatized as knowledge can be directly poured into students' brain, or spoon feeding. Therefore, students will passively learn, receive the knowledge and memorize the information from their teachers or textbooks. ${ }^{6}$

As the latest product of teacher training programme, novice teachers are expected to be trained with vivid understanding of the up-to-date teaching approaches and methods. Novice teachers need to adjust themselves with an array of roles and responsibilities, due to the challenging transition process from being student-teachers to in-service teachers. Hence, Organisation for Economic Co-Operation and Development (OECD) reported that a high quality of education in teacher training programme could not guarantee on fully preparing the novice teachers to adapt the challenges and issues they will be facing. ${ }^{7}$ There were variety of difficulties and unfamiliar conditions faced by the novice teachers during their beginning years of teaching.

\section{Knowing Novice Teachers}

Different countries have their own justification of classifying novice teachers' years for teaching. Tang, Kanokorn and Prachak in their study, provided a differentiation of year by each selected countries (See table 1). ${ }^{8}$ The scholars asserted that in Malaysia, novice teachers are subjected to attend and complete the induction course provided by Ministry of Education, and after going through officials' bureaucracies (certified by head of department and passed security clearance), then their statuses' will later be confirmed by Educational Services Commission. ${ }^{9}$

6 Daisy Christodoulou, Seven Myths About Education (Oxon: Routledge, 2013).

7 OECD, “A Teachers' Guide to TALIS 2013: Teaching and Learning International Survey" (OECD Publishing, 2014), https://doi.org/http://dx.doi.org/10.1787/9789264216075-en.

8 Keow Ngang Tang, Somprach Kanokorn, and Bouphan Prachak, "The Perspective of School Principals on Novice Teachers' Collective Work," Procedia Social and Behavioral Sciences 116 (2014): 2655-2659, https://doi.org/http://dx.doi.org/10.1016/j.sbspro.2014.01.630.

9 Tang, Kanokorn, and Prachak, "The Perspective of School Principals on Novice Teachers' Collective Work,” 2655-2659. 


\begin{tabular}{|l|l|l|}
\multicolumn{4}{|c|}{ Table 1 - Novice Teachers' Years of Teaching } \\
\hline \multicolumn{1}{|c|}{ Country } & $\begin{array}{l}\text { Years of } \\
\text { Teaching }\end{array}$ & \multicolumn{1}{|c|}{ Justification } \\
\hline New Zealand & 2 years & $\begin{array}{l}\text { Introduced as new qualified } \\
\text { teachers }\end{array}$ \\
\hline Singapore & 2 years & $\begin{array}{l}\text { National of Education provided } \\
\text { two years of coaching }\end{array}$ \\
\hline Japan & Nil & $\begin{array}{l}\text { Will be chosen as 'expert } \\
\text { teachers' if they have at least 10 } \\
\text { years of teaching experience }\end{array}$ \\
\hline Australia & $\begin{array}{l}\text { Less than } \\
3 \text { years }\end{array}$ & $\begin{array}{l}\text { Based on Australian Primary } \\
\text { Principal Reports }\end{array}$ \\
\hline Malaysia & $\begin{array}{l}\mathbf{1} \text { to 3 } \\
\text { years }\end{array}$ & $\begin{array}{l}\text { After they successfully } \\
\text { attended and completed } \\
\text { induction course }\end{array}$ \\
\hline
\end{tabular}

On the contrary, Fantilli and McDougall ${ }^{10}$ and Ibrahim $^{11}$ claimed that a novice teacher is a teacher that has less than five years teaching experiences. Howbeit, a handful number of teaching years is not an indicator for the novice teachers' potentials to build up their competencies in teaching profession. According to Farrell, there are numbers of factors that can influence novice teachers' competency development besides their initial experiences, nonetheless, from their socialisation process during the first year, previous schooling encounters and teacher training programme. ${ }^{12}$

\section{Novice Teachers' Practices in Teaching and Learning}

Much of current literature on novice teacher pay attention on the issues revolve around them, such as their implementation of

${ }^{10}$ Robert D. Fantilli and Douglas E. McDougall, "A Study of Novice Teachers: Challenges and Supports in the First Years," Teaching and Teacher Education 25

(2009):

814-825,

https://doi.org/http://dx.doi.org/10.1016/j.tate.2009.02.021.

${ }^{11}$ Ali S. Ibrahim, "Induction and Mentoring of Novice Teachers: A Scheme for the United Arab Emirates," Teacher Development 16, no. 2 (2012): 235-253, https://doi.org/http://dx.doi.org/10.1080/13664530.2012.688676.

12 Thomas S. C. Farrell, "Learning to Teach Language in the First Year: A Singapore Case Study," in Novice Language Teachers: Insights and Perspectives for the First Year, ed. Thomas S. C. Farrell (London: Equinox Publishing Ltd, 2008), 43-56. 
teaching and learning in and outside the classroom, lack of experiences and more. Teaching task can be daunting at times, but that is the stake to endure in order to grow as a competent and effective novice teacher. Novice teachers are facing a complex transition on translating the theories they have learnt during their teacher training programme into the real classroom. Novice teachers' incapability to translate the theory they have learnt into practises is noteworthy. Çakmak on his findings about novice teachers' thoughts about their initial years and pointed out that there were gap between practise and theory. ${ }^{13}$ This is also confirmed by Orgoványi-Gajdos in which he contended that novice teachers missed the link between knowledge and their action. $^{14}$

Several studies also attempted to distinguish on the novice teachers' classroom management. A study by Eteläpelto, Vähäsantanen and Hökkä showed that one of the factors in contributing obstacle to developing novice teachers' teaching practices were students' behaviours (due to their individual socioemotional problems). ${ }^{15}$ Novice teachers as unexperienced teachers often see their class management more in rules and disciplines, which they assess it from students' attention and their exhibition of acceptable behaviors in the classroom. ${ }^{16}$ In contrast with experienced teachers, where they are less stressed with the issue on having the authority to control the classroom, instead, their focus is pointed on the root cause of a problem, and to what extent

${ }^{13}$ Melek Çakmak, "Learning from Teaching Experiences: Novice Teachers' Thoughts," H. U. Journal of Education Special Is, no. 1 (2013): 55-67.

${ }^{14}$ Judit Orgoványi-Gajdos, "Expert and Novice Teachers' Approaches to Problematic Pedagogical Classroom Situations," in INTCESS15 - 2nd International Conference on Education and Social Sciences (Istanbul, Turkey, 2015), 591-600.

15 Anneli Eteläpelto, Katja Vähäsantanen, and Päivi Hökkä, "How Do Novice Teachers in Finland Perceive Their Professional Agency?," Teachers and Teaching: Theory and Practice 21, no. 6 (2015): 660-680, https://doi.org/http://dx.doi.org/10.1080/13540602.2015.1044327.

${ }^{16}$ Charlotte E. Wolff, Halszka Jarodzka, and Henny P.A. Boshuizen, "See and Tell: Differences between Expert and Novice Teachers' Interpretations of Problematic Classroom Management Events," Teaching and Teacher Education $66 \quad$ (2017): 295-308, https://doi.org/http://dx.doi.org/10.1016/j.tate.2017.04.015. 
they can improve the quality of their students' learning. ${ }^{17}$ This notion was also reported in Shohani et al., in which novice teachers have a low self-esteem, and inferior, hence, rate their performance low due to their inability to control one or two problematic students. ${ }^{18}$ A phenomenography study was conducted towards 18 novice teachers in Malaysia (between 1-3 years of teaching) found that merely knowing how to choose appropriate classroom and behaviour management strategies cannot help novice teachers if they unaware of the learning environment (students' way of learning). ${ }^{19}$

Not only classroom management as one of the elements in teaching practices, however, pedagogical content knowledge (PCK) also poses an important role. Novice teachers need to find a suitable teaching approaches and methods to ensure a condusive environment that facilitates learning. Kusnandi had outlined that teacher trainees who mastered PCK are able to create teachinglearning process that can actively involve students with befitting teaching approaches, methods and strategies. ${ }^{20}$ This is congruent with Syarifuddin and Halim, on their findings stated that novice teachers' level of understanding in PCK is at a moderate level. ${ }^{21}$ They also pointed out that the mastery of PCK is needed in order to deliver an effective teaching. Therefore, teachers' attitude and

${ }^{17}$ Wolff, Jarodzka, and Boshuizen, "See and Tell: Differences between Expert and Novice Teachers' Interpretations of Problematic Classroom Management Events," 295-308.

18 Saeedeh Shohani et al., "The Relationship between Novice and Experienced Teachers' Self-Efficacy for Personal Teaching and External Influences," Procedia - Social and Behavioral Sciences 185 (2014): 446-452.

${ }^{19}$ Pauline Swee Choo Goh and Kung Teck Wong, "Beginning Teachers' Conceptions of Competency: Implications to Educational Policy and Teacher Education in Malaysia," Educational Research for Policy and Practice 13, no. 1 (2014): 65-79, https://doi.org/http://dx.doi.org/10.1007/s10671-013-9147-3.

${ }^{20}$ H. Kusnandi, "Revitalization of Teacher Training Curriculum and Its Impact on Teacher Trainees' Teaching Performance: The Case of Galuh University," in Prosiding Seminar Pendidikan Transdisiplin (STed2017), ed. Jamaludin Badusah et al. (Fakulti Pendidikan, Universiti Kebangsaan Malaysia, Bangi: Fakulti Pendidikan, Universiti Kebangsaan Malaysia, 2017), 132-136.

${ }^{21}$ Noor Sairah Syarifuddin and Lilia Halim, "Amalan Pengetahuan Pedagogi Isi Kandungan Guru Baharu," in Prosiding Seminar Pendidikan Transdisiplin (STed2017), ed. Jamaludin Badusah et al. (Fakulti Pendidikan, Universiti Kebangsaan Malaysia, Bangi: Fakulti Pendidikan, Universiti Kebangsaan Malaysia, 2017), 682-690. 
the given opportunity to follow additional courses can contribute to the mastery in teaching. ${ }^{22}$

What is more, Nurashid and Hamzah found that teachers were burdened with academic and non-academic tasks such as preparing daily lesson plans, managing co-curricular activities, conducting student programs, managing administrative duties and attending programs organised by the Ministry of Education, State Education Department, District Education Office and schools. ${ }^{23}$ This burden of duty has slightly affected the quality of teacher teaching. In order to create an excellent generation of Muslims, Islamic education teachers are not excluded from being constantly faced with a myriad of challenges in carrying out their duties. Amongst these challenges also are Islamic education teachers' own internal problems, heavy teaching workloads, student backgrounds and lack of pedagogical courses ${ }^{24}$. Previous studies reported that Islamic education teachers' heavy workload and time constraints to teach al-Quran recitation has contributed to the impediment of teachers' effective teaching in various teaching and learning activities. ${ }^{25}$

\section{Research Objectives}

Hence, the objectives of this research are;

1. To identify the application of teaching and learning approaches in Islamic Education novice teachers' classroom.

2. To investigate issues and challenges in Islamic Education novice teachers' pedagogical practices that they encounter during their early years of teaching.

${ }^{22}$ Syarifuddin and Halim, “Amalan Pengetahuan Pedagogi Isi Kandungan Guru Baharu," 682-690.

${ }^{23}$ Norashid Othman and Hamzah Md Omar, "Beban Tugas dan Motivasi Pengajaran Guru di Sekolah Menengah Daerah Ranau," Jurnal Pemikir Pendidikan 5, no. 1 (2014): 33-57.

${ }^{24}$ Siti Rashidah Abd Razak et.al, "Cabaran Guru Pendidikan Islam dalam Pembentukan Akhlak Pelajar," Journal Of Social Sciences and Humanities 1, no. 3 (2016): 100-110.

${ }^{25}$ Mohd Aderi Che Noh, Mohd Sofian Mat Ludin, and Asmawati Suhid, "Teaching Competency among Islamic Educators in Malaysia," World Applied Sciences Journal 24, no. 2 (2013): 267-269. 


\section{Research Methodology \\ Research Design}

Creswell defines qualitative research "as a study which begins with assumptions, a worldview, the possible use of a theoretical lens, and the study of research problems inquiring into the meaning individuals or groups ascribe to a social or human problem". ${ }^{26}$ This coincides with Merriam and Tisdell who stated that the purpose of qualitative research is to understand the meaning that people have constructed. ${ }^{27}$ By reviewing definitions, the curiosity was triggered by an assumption of certain phenomena or situation that conducted and performed by the human. In this research context, researcher opted for qualitative research design in order to explore and identify Islamic Education novice teachers' teaching practices during their early years of services in secondary schools.

\section{Research Sample}

Research participants were amongst secondary school Islamic education novice teachers from four different zones (north, south, east coast and East Malaysia), that were recruited by using purposive sampling. Purposive sampling was applied to identify and select research participants because it enabled the incorporation of the research interest and purpose. ${ }^{28}$ Therefore, ten novice teachers who served less than five years of teaching were chosen to be the main criteria for this study. The Islamic education novice teachers will be tagged as ISNT1 to ISNT10 in order to replace their real name and maintain the confidentiality.

\section{Research Instruments}

As a method of data collection, semi-structured individual interviews were conducted by having a two-way interaction process to obtain information from research participants. According to Yin, it is a must to have a framework or protocol in

${ }^{26}$ John W. Creswell, Qualitative Inquiry and Research Design: Choosing Among Five Approaches, 2nd ed. (Thousand Oaks, CA: Sage Publications, Inc, 2007), 37.

${ }^{27}$ Sharan B Merriam and Elizabeth J Tisdell, Qualitative Research: A Guide to Design and Implementation, 4th ed. (San Francisco: Jossey-Bass, 2016).

${ }^{28}$ Creswell, Qualitative Inquiry and Research Design: Choosing Among Five Approaches. 
order to remain consistent with the objectives of the research. ${ }^{29}$ Therefore, a set of interview protocol had been sent to panel of experts to verify the validity. Other than that, researchers need to maintain flexibility in responding towards any issues that emerge spontaneously while interviewing through dialogue and interactions. In any case, any spontaneous issues are welcomed and researchers are able to redirect the flow back to the research context. All interviews took around 45 to 60 minutes per novice teachers to ensure the data is unique and sufficient.

\section{Data Analysis}

Data from all interviews has been transcribed and for quotation purposes, it was translated from Malay to English. Thus, it comes with a challenge to ensuring the researcher to keep close with the original context. Afterwards, all data were coded and analysed thematically to define differences and repeatable ideas by using Miles and Huberman's Interaction Model. ${ }^{30}$

\section{Findings and Discussions}

\section{Teachers' Acknowledgement of Student as the Heart of Learning}

As the result of globalisation, novice teachers are envisaged to conduct their teaching and learning process into student-centred. Student-activating teaching is "an approach that stimulates students to construct knowledge by means of real life, realistic, practical and relevant assignments that requiring students' active involvement to incorporate available information". ${ }^{31}$ Implementing student as the heart of learning means the teachers need to help students to set goals, encourage students to assess their own learning outcomes, help them work together in groups, and ensure they know how to use all available learning resources.

${ }^{29}$ Robert K. Yin, Qualitative Research from Start to Finish (New York: The Guilford Press, 2011).

${ }^{30}$ Matthew B Miles and A. Michael Huberman, Qualitative Data Analysis, 2nd ed. (Thousand Oaks, CA: Sage Publications, Inc, 1994).

${ }^{31}$ Katrien Struyven, Filip Dochy, and Steven Janssens, “'Teach as You Preach': The Effects of Student-Centred versus Lecture-Based Teaching on Student Teachers' Approach to Teaching," European Journal of Teacher Education 33, no. 1 (2010): 44. 
"If I have a large number of students in class, I will ask them to create an I-think map on their own and do a gallery walk. Since my class was held at the musolla, my students are cooperating well." - ISNT1

"I did lots of activities in class, such as hot seats, dragon ball, musical chairs etc. It can be seen that my students are less sleepy during my teaching and enthusiastic to learn." ISNT10

The data above showed that both Islamic education novice teachers employed methods and techniques that were featured in $21^{\text {st }}$ Century Education. This $21 \mathrm{st}$ Century Learning has transformed the dynamics of education into technology-friendly, which has various methods that can be applied in teaching Islamic education and meets the latest needs. ${ }^{32}$ Learners who are directly involved in their learning are expected to put their own commitment to learn along with the help of their peers and constantly under the guidance of the teacher. Ultimately, by actively engaging in the learning process, they are more exposed to problem-solving skills, upgrading their communication skill, working in team and more.

"It is hard if I want to get the new information from my students. Since they did not give full cooperation in that area, it is important to make the learning session fun, like singing, and sometime I used m-learning as well." - ISNT2

Nur Atikah and Tengku Sarina, on the uses of mobile phones in Islamic education amongst novice teachers in Sabah has a positive impact for its potential to becoming a supporting tools during teaching and learning. ${ }^{33}$ Furthermore, it also assist novice teachers in providing students an alternative way to learn independently, or as a way to communicate through learning by

${ }^{32}$ Tengku Sarina Aini Tengku Kasim et al., "Pendekatan Konstruktivisme Di Malaysia Dan Brunei Darussalam: Satu Tinjauan Awal Terhadap Pengalaman Guru Pendidikan Islam," Journal of Islamic Educational Research 2, no. 1 (2017): 23-35.

${ }^{33}$ Nur Atikah Miasan and Tengku Sarina Aini Tengku Kasim, "Penggunaan MPembelajaran dalam Kalangan Guru Novis Pendidikan Islam di Sabah," in Proceeding of the 2nd International Conference on Islamic Education And Law (2nd ICIEL) (Perdana Hotel, Kota Bharu: Global Academic Excellence, 2018), 196-205. 
using 'Twitter', 'Kahoot' and more. By doing this, students can create their own 'learning artifact' as evidence of learning. ${ }^{34}$

\section{Accepting $21^{\text {st }}$ Century Education}

Few years before the introduction of KSSM, teachers or school administrators are requested to follow a standard curriculum, for example, the 21st Century Education (Pendidikan Abad ke-21) ${ }^{35}$ and the Higher Order Thinking Skills (HOTS) ${ }^{36}$ Whereby the idea is concerning on ensuring the curriculum serves in fulfilling a basic human need, in developing the potential of individuals, including the personality of the spiritual, physical, intellectual and moral through a holistic education. Yet, it received a mixed review from Islamic education novice teachers as can be seen at Table 2 .

\section{Table 2 - Islamic Education Novice Teachers'} Views on $21^{\text {st }}$ Century Education

\begin{tabular}{|l|l|}
\hline ISNT1 & $\begin{array}{l}21^{\text {st }} \text { century education is efficient. It does not need us } \\
\text { as teacher to teach } 100 \text { percent in class, or learning by } \\
\text { referring on textbooks only. }\end{array}$ \\
\hline ISNT5 & $\begin{array}{l}\text { Maybe the 21st Century Education is suitable for top } \\
\text { classes. If we implement it for last classes, it is so } \\
\text { challenging. }\end{array}$ \\
\hline ISNT7 & $\begin{array}{l}\text { For 'last classes', I definitely did not apply 21st } \\
\text { Century Education. }\end{array}$ \\
\hline ISNT9 & $\begin{array}{l}\text { 21st Century Education teaching methods, it is fun for } \\
\text { my students. They did not fall asleep in class as they } \\
\text { are having fun. That is the specialty of 21st Century } \\
\text { Education. }\end{array}$ \\
\hline
\end{tabular}

Data showed that ISNT1 and ISNT9 are fully supported the changes brought by the Ministry of Education. It has its own advantages in teaching and learning as it is not merely based on using textbooks alone, but incorporating thinking skills as well.

\footnotetext{
${ }^{34}$ Ben Curran and Neil Wetherbee, Engaged, Connected, Empowered: Teaching and Learning in the 21 st Century (New York: Routledge, 2014).

${ }^{35}$ Institut Aminuddin Baki, Panduan Pelaksanaan Pendidikan Abad Ke-21 (Negeri Sembilan: Institut Aminuddin Baki, Ministry of Education Malaysia, 2017), 3.

${ }^{36}$ MoE Malaysia, Elemen KBAT Dalam Pedagogi (Putrajaya: Curriculum Development Division, Ministry of Education Malaysia, 2014), 1.
} 
This in agreement with Othman and Kassim, who claimed that teachers' process of teaching and learning in Islamic education should be prospered by relating current situations with a practical knowledge, and not based on abstract knowledge. ${ }^{37}$ As a result, students are expected to master multiple expertise, emphasize on deep understanding rather than surface knowledge, also engaging with real material world that they will encounter in the future ${ }^{38}$.

Macklem, defined boredom as 'experienced due to lack of activity or being disengaged from a satisfying activity'. ${ }^{39}$ Instead of having class with no satisfying activity, $21^{\text {st }}$ Century Education offered a fun and engaging way to learn. ISNT9 are able to switch her teaching methods into an active learning and have some direct control over her students' emotions in class. Furthermore, this is supported with Jasmi's findings on active learning in Islamic education that showed students are able to master the contents, quickly remember the facts, more focus on discussions and their engagement, improve their speaking skills and cultivate learning interest. $^{40}$

On the other hand, ISNT5 and ISNT7 were not implementing $21^{\text {st }}$ Century Education for the last classes. Last classes were often dubbed as problematic students, less interest in learning, passive students and more. Thus, Islamic education novice teachers need to build the students' confidence during the learning process so that they are confident to voluntarily engaging in their learning activities. ${ }^{41}$ Also, teachers need to play a role as a guide and hear

${ }^{37}$ Mohd Syaubari Othman and Ahmad Yunus Kassim, "Elemen Kemahiran Berfikir Aras Tinggi (KBAT) Di Dalam Amalan Pengajaran Guru Pendidikan Islam Menurut Imam Ghazali," Jurnal Sultan Alauddin Sulaiman Shah 3, no. 2 (2016): 80-91.

${ }^{38}$ Halah Ahmed Alismail and Patrick McGuire, "21st Century Standards and Curriculum: Current Research and Practice," Journal of Education and Practice 6, no. 6 (2015): 150-154.

${ }^{39}$ Gayle L. Macklem, Boredom in the Classroom: Addressing Student Motivation, Self-Regulation, and Engagement in Learning (New York: Springer, 2015), 1.

${ }^{40}$ Kamarul Azmi Jasmi, "Pembelajaran Aktif dalam Pendidikan Islam: Pengamalan Guru Cemerlang Pendidikan Islam," in Seminar Pemerkasaan Pengajaran Agama Islam Di Malaysia (Main Hall of Institut Kefahaman Islam Malaysia (IKIM), 2013), 1-16.

${ }^{41}$ Tengku Sarina Aini Tengku Kasim and Fatimah Sahida Abdurajak, "Pengalaman Pengajaran Guru Novis Pendidikan Islam: Implikasi Terhadap 
students' opinions, as well as to let them to be the presenter in the classroom. Teachers also need to give the right to freedom of speech to the students, as it promotes an encouraging interaction amongst students. The teachers' trust in their students to provide students' autonomy in the teaching and learning process will increase their motivation to learn and cooperate.

\section{Conclusion}

The application of the methods of teaching in the 21st Century Education inevitably required Islamic Education novice teachers to adapt student-centred approach as the policy will reflect around students as the core of learning. This insight can help to understand the importance of Islamic education novice teachers' roles in successfully implementing the new education change. In short amount of time and experiences in Islamic education novice teachers beginning years, they were found in needing lots of rooms for improvements in their pedagogical practices. They shoulder the responsibilities of teaching the values of Islam, with embracing the new life which based on intelligent technology. It is undeniable that Malaysia's initiatives on 21 st century education with incorporating fourth Industrial Revolution can serve as a benchmark in enhancing teachers' quality, together with their pedagogical competencies in order to provide world-class education frameworks.

\section{Acknowledgement}

Researchers would like to thank Institute of Research Management and Monitoring, University of Malaya for granting the research grants. This paper is resulted from research funded by UMRG (RP014A-13HNE) and UMRG (RP029B-16HNE).

\section{References}

Abd Razak et al. "Cabaran Guru Pendidikan Islam dalam Pembentukan Akhlak Pelajar." Journal Of Social Sciences and Humanities 1, no. 3 (2016): 100-110.

AbuMezied, Asmaa. "What Role Will Education Play in the Fourth Industrial Revolution?" World Economic Forum, 2018.

Reka Bentuk Kurikulum Latihan Pendidikan Guru," Jurnal Pendidikan Malaysia 43, no. 1 (2018): 59-66. 
https://www.weforum.org/agenda/2016/01/what-role-willeducation-play-in-the-fourth-industrial-revolution/. Retrieved on 16 April 2018.

Alismail, Halah Ahmed, and Patrick McGuire. "21st Century Standards and Curriculum: Current Research and Practice." Journal of Education and Practice 6, no. 6 (2015): 150-154.

Aliusta, Gülen Onurkan, and Bekir Özer. "Student-Centred Learning (SCL): Roles Changed?" Teachers and Teaching: Theory and Practice, 23, no. 4 (2017): 422-435.

Çakmak, Melek. "Learning from Teaching Experiences: Novice Teachers' Thoughts." H. U. Journal of Education Special Is, no. 1 (2013): 55-67.

Christodoulou, Daisy. Seven Myths About Education. Oxon: Routledge, 2013.

Creswell, John W. Qualitative Inquiry and Research Design: Choosing Among Five Approaches. 2nd ed. Thousand Oaks, CA: Sage Publications, Inc, 2007.

Curran, Ben, and Neil Wetherbee. Engaged, Connected, Empowered: Teaching and Learning in the 21st Century. New York: Routledge, 2014.

Eteläpelto, Anneli, Katja Vähäsantanen, and Päivi Hökkä. "How Do Novice Teachers in Finland Perceive Their Professional Agency?" Teachers and Teaching: Theory and Practice 21, no. 6 (2015): 660-680. https://doi.org/http://dx.doi.org/10.1080 /13540602.2015.1044327.

Fantilli, Robert D., and Douglas E. McDougall. "A Study of Novice Teachers: Challenges and Supports in the First Years." Teaching and Teacher Education 25 (2009): 814-825. https://doi.org/http://dx.doi.org/10.1016/j.tate.2009.02.021.

Farrell, Thomas S. C. "Learning to Teach Language in the First Year: A Singapore Case Study." In Novice Language Teachers: Insights and Perspectives for the First Year, edited by Thomas S. C. Farrell, 43-56. London: Equinox Publishing Ltd, 2008.

Goh, Pauline Swee Choo, and Kung Teck Wong. "Beginning Teachers' Conceptions of Competency: Implications to Educational Policy and Teacher Education in Malaysia." Educational Research for Policy and Practice 13, no. 1 (2014): 65-79. https://doi.org/http://dx.doi.org/10.1007/s10671-0139147-3. 
Ibrahim, Ali S. "Induction and Mentoring of Novice Teachers: A Scheme for the United Arab Emirates." Teacher Development 16, no. 2 (2012): 235-253. https://doi.org/http://dx.doi.org /10.1080/13664530.2012.688676.

Institut Aminuddin Baki. Panduan Pelaksanaan Pendidikan Abad $K e-21$. Negeri Sembilan: Institut Aminuddin Baki, Ministry of Education Malaysia, 2017.

Kamarul Azmi Jasmi. "Pembelajaran Aktif dalam Pendidikan Islam: Pengamalan Guru Cemerlang Pendidikan Islam." Paper presented in Seminar Pemerkasaan Pengajaran Agama Islam Di Malaysia, 1-16. Main Hall of Institut Kefahaman Islam Malaysia (IKIM), 2013.

Kusnandi, H. "Revitalization of Teacher Training Curriculum and Its Impact on Teacher Trainees' Teaching Performance: The Case of Galuh University." In Prosiding Seminar Pendidikan Transdisiplin (STed2017), edited by Jamaludin Badusah, Norazah Nordin, Mardina Abdullah, Kamal Halili Hassan, Nor Fariza Mohd Nor, Mohd Juzaiddin Ab Aziz, Marlia Mohd Hanafiah, Wan Muna Ruzanna Wan Mohammad, Helmi Norman, and Nurul Aisyah Kamrozzaman, 132-136. Fakulti Pendidikan, Universiti Kebangsaan Malaysia, Bangi: Fakulti Pendidikan, Universiti Kebangsaan Malaysia, 2017.

Macklem, Gayle L. Boredom in the Classroom: Addressing Student Motivation, Self-Regulation, and Engagement in Learning. New York: Springer, 2015.

Maizatul Ranai. "2018 MANDATE: Embracing Industry 4.0." Ministry of Higher Education Malaysia, 2018. http://news.mohe .gov.my/2018/01/27/2018-mandate-embracing-industry-4-0/.

Retrieved on 16 April 2018.

Merriam, Sharan B, and Elizabeth J Tisdell. Qualitative Research: A Guide to Design and Implementation. 4th ed. San Francisco: Jossey-Bass, 2016.

Miles, Matthew B, and A. Michael Huberman. Qualitative Data Analysis. 2nd ed. Thousand Oaks, CA: Sage Publications, Inc, 1994.

Mohd Aderi Che Noh, Mohd Sofian Mat Ludin, and Asmawati Suhid. "Teaching Competency among Islamic Educators in Malaysia." World Applied Sciences Journal 24, no. 2 (2013): 267-269. 
MoE Malaysia. Buku Penerangan Kurikulum Standard Sekolah Menengah. Putrajaya: Curriculum Development Division, Ministry of Education, 2016.

- Elemen KBAT Dalam Pedagogi. Putrajaya: Curriculum Development Division, Ministry of Education Malaysia, 2014. OECD. "A Teachers' Guide to TALIS 2013: Teaching and Learning International Survey." OECD Publishing, 2014. https://doi.org/http://dx.doi.org/10.1787/9789264216075-en.

Orgoványi-Gajdos, Judit. "Expert and Novice Teachers' Approaches to Problematic Pedagogical Classroom Situations." In INTCESS15 - 2nd International Conference on Education and Social Sciences, 591-600. Istanbul, Turkey, 2015.

Mohd Syaubari Othman and Ahmad Yunus Kassim. "Elemen Kemahiran Berfikir Aras Tinggi (KBAT) di dalam Amalan Pengajaran Guru Pendidikan Islam Menurut Imam Ghazali." Jurnal Sultan Alauddin Sulaiman Shah 3, no. 2 (2016): 80-91.

Noor Sairah Syarifuddin and Lilia Halim. "Amalan Pengetahuan Pedagogi Isi Kandungan Guru Baharu." In Prosiding Seminar Pendidikan Transdisiplin (STed2017), edited by Jamaludin Badusah, Norazah Nordin, Mardina Abdullah, Kamal Halili Hassan, Nor Fariza Mohd Nor, Mohd Juzaiddin Ab Aziz, Marlia Mohd Hanafiah, Wan Muna Ruzanna Wan Mohammad, Helmi Norman, and Nurul Aisyah Kamrozzaman, 682-690. Fakulti Pendidikan, Universiti Kebangsaan Malaysia, Bangi: Fakulti Pendidikan, Universiti Kebangsaan Malaysia, 2017.

Norashid Othman and Hamzah Md Omar. "Beban Tugas dan Motivasi Pengajaran Guru Di Sekolah Menengah Daerah Ranau." Jurnal Pemikir Pendidikan 5, no. 1 (2014): 33-57.

Nur Atikah Miasan and Tengku Sarina Aini Tengku Kasim. "Penggunaan M-Pembelajaran dalam Kalangan Guru Novis Pendidikan Islam di Sabah." In Proceeding of the 2nd International Conference on Islamic Education And Law (2nd ICIEL), 196-205. Perdana Hotel, Kota Bharu: Global Academic Excellence, 2018.

Shohani, Saeedeh, Akbar Azizifar, Habib Gowhary, and Ali Jamalinesari. "The Relationship between Novice and Experienced Teachers' Self-Efficacy for Personal Teaching and External Influences." Procedia - Social and Behavioral Sciences 185 (2014): 446-452. 
Struyven, Katrien, Filip Dochy, and Steven Janssens. “Teach as You Preach': The Effects of Student-Centred versus LectureBased Teaching on Student Teachers' Approach to Teaching." European Journal of Teacher Education 33, no. 1 (2010): 4364.

Tang, Keow Ngang, Somprach Kanokorn, and Bouphan Prachak. "The Perspective of School Principals on Novice Teachers' Collective Work." Procedia Social and Behavioral Sciences 116 (2014): 2655-59. https://doi.org/http://dx.doi.org/10.1016 /j.sbspro.2014.01.630

Tengku Sarina Aini Tengku Kasim and Fatimah Sahida Abdurajak. "Pengalaman Pengajaran Guru Novis Pendidikan Islam: Implikasi Terhadap Reka Bentuk Kurikulum Latihan Pendidikan Guru." Jurnal Pendidikan Malaysia 43, no. 1 (2018): 59-66.

Tengku Sarina Aini Tengku Kasim, et al. "Pendekatan Konstruktivisme di Malaysia dan Brunei Darussalam: Satu Tinjauan Awal Terhadap Pengalaman Guru Pendidikan Islam." Journal of Islamic Educational Research 2, no. 1 (2017): 23-35. Wolff, Charlotte E., Halszka Jarodzka, and Henny P.A. Boshuizen. "See and Tell: Differences between Expert and Novice Teachers' Interpretations of Problematic Classroom Management Events." Teaching and Teacher Education 66 (2017): 295-308. https://doi.org/http://dx.doi.org/10.1016/j.tate .2017.04.015.

World Economic Forum. "ASEAN 4.0: What Does the Fourth Industrial Revolution Mean for Regional Economic Integration?," Geneva: World Economic Forum and Asian Development Bank, 2017.

Yin, Robert K. Qualitative Research from Start to Finish. New York: The Guilford Press, 2011. 
Sarina and Fatimah, Heart of Learning 